\title{
ZÁKLAD DANĚ - SUPERHRUBÁ MZDA VERSUS HRUBÁ MZDA ZAMĚSTNANCE
}

\section{Marcela Prausová}

\section{Klíčová slova:}

Mzda, superhrubá mzda, základ daně, zdravotní a sociální pojištění, daň z příjmu fyzických osob, rovná daň, progresivní zdanění.

\section{Keywords:}

Wage, super wage, tax base, Health Insurance, Social Insurance, tax on personal income, flat tax, progressive taxation.

\begin{abstract}
Abstrakt
Zavedení institutu superhrubé mzdy představuje pro poplatníky daně z příjmů ze závislé činnosti významnou změnu. Do konce roku 2007 byl základem daně hrubý př́jem zaměstnance, přičemž bylo uplatňováno tzv. progresivní zdanění. Aplikace konceptu superhrubé mzdy způsobila významné navýšení daňového základu, současně se změnil způsob zdanění na tzv. rovné a v platnost vstoupila jednotná daň z př́ijmu fyzických osob se sazbou ve výši $15 \%$.
\end{abstract}

\begin{abstract}
Introduction of a super-gross income represent an important change for the end of 2007 an employee's gross income was a tax base and at the same time the progress taxation was applied. Installation of a supergross income concept has caused an important increase of a tax base and a way of taxation was transformed into so called an equal taxation and the new equal tax at rate of 15 percent came into force as well.
\end{abstract}

\section{Úvod}

Odměna za vykonanou práci - mzda či plat, přestavuje klíčový nástroj k odměňování zaměstnanců. Samotná výše mzdy je jedním z motivačních faktorů, který mnohdy rozhoduje o tom, zda zaměstnanec bude ochoten pracovat, či se mu vyplatí, zařadit se mezi dobrovolně nezaměstnané a využívat sociální dávky vyplácené státem v podobě hmotného zabezpečení v nezaměstnanosti. Výši čisté mzdy zaměstnance ovlivňuje několik faktorů - sazba daně z př́jmu fyzických osob, procentuální sazba odvodů na pojistném i metodika zdanění. Zřejmě nejdůležitějším kritériem pro určení výše čisté mzdy zaměstnance je však definování daňového základu. Jeho vymezení představuje zachování principu spravedlnosti.

Cílem příspěvku je definování jednoho ze základních nástrojů konstrukčních prvků daně základu daně, na prríkladech demonstrovat dopady daňového působení na zaměstnance jako daňového poplatníka při rozdílně stanoveném základu daně - superhrubé a hrubé mzdě. Současně simulovat působení lineární jednotné sazby daně spolu s aplikací slev na dani a daňového zvýhodnění na čistý př́íjem zaměstnance. 


\section{Daň z příjmu fyzických osob v ČR}

Daň z př́ijmů fyzických osob představuje svojí konstrukcí nejsložitější daň celého daňového systému ČR. Snad nejvýznamnějším zdaněním v rámci daně z př́ijmu fyzických osob je zdanění mezd, neb většina $\mathrm{z}$ nás je v zaměstnaneckém poměru.

Př́ijmy ze zaměstnání představují cca $60 \%$ ní ${ }^{1}$ podíl na celkových př́ímech domácností v ČR. Podíl na zdanitelných př́ijmech domácností je asi $80 \%$.

Příjmem ze závislé činnosti je př́ijem ze současného nebo dřívějšího pracovněprávního, služebního či členského a obdobného poměru, v němž poplatník při výkonu práce pro plátce př́ijmu je povinen dbát př́kazů plátce ${ }^{2}$.

Poplatníky daně z př́immů ze závislé činnosti jsou zaměstnanci, tedy ti, kteří vykonávají pro svého zaměstnavatele práci a ten jim za ni poskytuje odměnu v podobě mzdy či platu.

Mimo př́ijmy ze zdanění mezd se za příjmy ze závislé činnosti považují také př́íjmy z:

a) práce členů družstva pro družstvo, společníků společnosti s ručením omezeným, komanditistů komanditních společností i jednatelů, a to i v situaci, že nejsou v zaměstnaneckém poměru dané společnosti

b) tantiém

c) náhrad

d) funkčních požitků

Sazba daně z př́ijmů fyzických osob se mění v závislosti na ekonomicko-politických rozhodnutích. V letech 1993 - 2007 byla v České republice klouzavě progresivní. Progresivita zdanění vycházela ze čtyř daňových pásem. Nejnižší dvanáctiprocentní sazbou daně byli zdaněni zaměstnanci s nejnižším hrubým příjmem. Zaměstnanci s nadprůměrnými př́immy byli zdaněni horní sazbou daně ve výši $32 \%{ }^{3}$. Od roku 2008 je v ČR stanovena jednotná lineární ${ }^{4}$ sazba daně ve výši $15 \%$.

\section{Daňový základ - superhrubá mzda versus hrubá mzda zaměstnance}

Základem daně je předmět daně vyjádřený v měrných jednotkách a upravený podle pravidel. Musí být vyjádřený hodnotově, tj. v korunách, nebo ve fyzikálních jednotkách. Odvození základu daně představuje klíčový faktor pro určení daňové povinnosti. S určením základu daně úzce souvisí i typ uvalené daně. Právě tyto klíčové nástroje prvků daňové techniky způsobují odlišnosti ve zdaňování mzdy v různých ekonomikách.

V České republice se od 1. ledna 2008 stala daňovým základem, tzv. superhrubá mzda. Tento termín představuje součet hrubé mzdy zaměstnance a odvodů na pojistném (veřejné zdravotní pojištění a sociální pojištění v celkové výši $34 \%$ z hrubého př́íjmu zaměstnance) podniku. Princip superhrubé mzdy zakotvuje $§ 6$ odst. 13 Zákona o daních z př́ijmů (dále jen ZDP).

\footnotetext{
${ }^{1}$ Údaj zjištěný k roku 2009 (statistické šetření životní podmínky, ČSÚ).

${ }^{2}$ Viz $§ 6$ odst. 1 písm. a) zákona o daních z příjmů.

${ }^{3}$ Při klouzavé progresi se základ daně určité velikosti postupně zdaňuje jednotlivými úrovněmi sazby daně, kterými základ daně prochází.

${ }^{4}$ Lineární sazba představuje dan̆ rostoucí s růstem základu daně ve stejném poměru.
} 
Níže uvedené schéma 1 zobrazuje konstrukci daňového základu u daně z př́immů ze závislé činnosti, aplikovaného v ČR od roku 2008. Kromě hrubého př́ijmu zahrnuje také zmiňované odvody na pojistném zaměstnavatele.

\section{Schéma 1: Odvození základu daně z příjmů ze závislé činnosti při aplikaci konceptu superhrubé mzdy}

Hrubý příjem zaměstnance za kalendářní měsíc (včetně nepeněžitých př́ijmů)

- Př́ijmy vyňaté

- Př́́jmy osvobozené od daně

= Hrubá mzda

+ Pojistné na sociální zabezpečení hrazené zaměstnavatelem

+ Pojistné na veřejné zdravotní pojištění hrazené zaměstnavatelem

= Základ daně pro vyčíslení zálohy

Takto zjištěný základ daně zaokrouhlíme na celá sta nahoru a vynásobíme jednotnou lineární sazbou daně ve výši $15 \%$ (sazba platná od roku 2008 dosud), čímž zjistíme základní částku zálohy na daň.

Tuto zjištěnou základní částku ponížíme o slevy na dani a daňové zvýhodnění. Slevy na dani představují částky, které přímo snižují daňovou povinnost důchodových daní. ${ }^{5}$ Základní uplatňovanou slevou v roce 2012 je sleva na poplatníka ve výši 2070 Kč měsíčně (ročně $24080 \mathrm{Kč})$.

\section{Mezi další slevy náleží}

1) Daňové zvýhodnění na dítě - ročně 13404 Kč, 1117 Kč (měsíčně)

2) sleva na manželku/la s př́ijmem do 68000 Kč - ročně 24840 Kč, (měsíčně se neuplatňuje, pouze ročně)

3) sleva na studenta - ročně 4020 Kč, 335 Kč (měsíčně),

4) sleva držitele průkazu ZTP/P - ročně 16140 Kč, 1345 Kč (měsíčně),

5) sleva na invaliditu I. a II. stupně - ročně 2520 Kč, 210 Kč (měsíčně),

6) sleva na invaliditu III. stupně - ročně 5040 Kč, 420 Kč (měsíčně)

Rok 2013 přinese v oblasti zdanění prřijmů ze závislé činnosti důležité změny. Tou nejvýznamnější je zrušení superhrubé mzdy, která představuje daňový základ pro zjištění daňové povinnosti poplatníka dnes. Nově bude daňovým základem opět pouze hrubý př́jem zaměstnance. Schéma 2 znázorňuje odvození daňového základu aplikovaného od roku 2013.

\section{Schéma 2: Odvození základu daně z příjmů ze závislé činnosti při zrušení konceptu superhrubé mzdy}

Hrubý př́ijem zaměstnance za kalendářní měsíc (včetně nepeněžitých příjmů)

- Př́jimy vyňaté (např. náhrady cestovních výdajů, poskytnuté pracovní pomůcky, oděvy)

- Př́jmy osvobozené od daně (zaměstnanecké benefity)

= Hrubá mzda $=$ Základ daně pro vyčíslení zálohy

\footnotetext{
${ }^{5}$ ŠIROKÝ, J.: Daňová teorie. C. H. Beck. Praha, 2008

${ }^{6}$ Zákon č. 586/1992 Sb., o daních z př́ijmů
} 
Schéma 2 jasně demonstruje významný pokles základu daně uplatňovaného od roku 2013, kdy dojde ke zrušení superhrubé mzdy.

S touto změnou koresponduje změna sazby daně z př́ijmů fyzických osob. Základ daně místo současných $15 \%$ bude nově zatîžen stanovenou jednotnou sazbou daně ve výši $19 \%$. Nárůst sazby DPFO je o 4 procentní body. Současně se změnou stanovení základu daně a zvýšením sazby daně pro zjištění zálohy na DPFO, se zvyšuje také procentuální sazba pojistného na veřejné zdravotní pojištění placené zaměstnancem, a to ze současných $4,5 \%$ na 6,5 \%. Základem pro zjištění výše pojistného zůstane hrubá mzda, čímž dojde ke sjednocení základů pro výpočet zálohy na daň i odvodů na pojistném zaměstnance.

$\mathrm{Z}$ uvedených údajů provedeme simulaci výpočtu daňové povinnosti u zaměstnance, jehož hrubá mzda činí 24126 Kč (celková průměrná mzda za I. čtvrtletí 2012) Zdanění je realizováno v roce 2012 a 2013. Nepočítáme se slevami na dani.

Tabulka 1 A, B: Daňová povinnost zaměstnance s hrubou mzdou 21126 Kč bez uplatnění daňových úlev a slev na dani v letech 2012 a 2013

\begin{tabular}{|l|r|}
\hline \multicolumn{1}{|c|}{ A } & $\mathbf{2 0 1 2}$ \\
\hline Hrubá mzda & 24126 \\
\hline Základ daně & 32400 \\
\hline Daňová povinnost & 4860 \\
\hline
\end{tabular}

Zdroj: vlastní zpracování autora

\begin{tabular}{|l|r|}
\hline \multicolumn{1}{|c|}{ B } & $\mathbf{2 0 1 3}$ \\
\hline Hrubá mzda & 24126 \\
\hline Základ daně & 24126 \\
\hline Daňová povinnost & 4584 \\
\hline
\end{tabular}

Zdroj: vlastní zpracování autora

Z výsledků vyplývá úspora 276 Kč ve prospěch roku 2013.

Vývoj výše zdanění (před uplatněním daňového zvýhodnění a slev na dani) při užití současné lineární sazby daně můžeme demonstrovat při narůstajícím hrubém př́ijmu zaměstnance.

Počítejme tedy s hrubým příjmem zaměstnance v následující výši (viz. údaje v tabulce) při stanovení jednotné lineární daně ve výši $15 \%$.

Tabulka 2: Vývoj výše daně při růstu daňového základu v roce 2012

\begin{tabular}{|c|c|c|c|c|}
\hline \multicolumn{5}{|c|}{ Rok 2012 } \\
\hline Hrubá mzda & Základ daně & Daň 15\% & Po zdanění & Efektivní daň \\
\hline 8000 & 10800 & $\mathbf{1 ~ 6 2 0}$ & 6380 & $15 \%$ \\
\hline 10000 & 13400 & $\mathbf{2 ~ 0 1 0}$ & 7990 & $15 \%$ \\
\hline 15000 & 20100 & $\mathbf{3 0 1 5}$ & 11985 & $15 \%$ \\
\hline 20000 & 26800 & $\mathbf{4 0 2 0}$ & 15980 & $15 \%$ \\
\hline 25000 & 33500 & $\mathbf{5 0 2 5}$ & 19975 & $15 \%$ \\
\hline 30000 & 40200 & $\mathbf{6 ~ 0 3 0}$ & 23970 & $15 \%$ \\
\hline
\end{tabular}

Zdroj: vlastní zpracování autora 
Zjištěné výsledky v tabulce 2 (sloupec daň $15 \%$ ) naznačují vývoj daňové povinnosti při růstu daňového základu. Lze vyčíst poměr mezi daňovým základem a výší daně, čímž zjistíme průměrnou sazbu daně, označovanou též jako efektivní sazba daně, které dle zadaných údajů zůstává neměnná ve výši $15 \%$. Efektivní sazba daně by se měnila, pokud bychom využili například slevy na poplatníka. Čistý příjem zaměstnance se zvýšil o hodnotu slevy.

Níže uvedený obrázek naznačuje průběh lineární sazby daně, v němž je znázorněn poměr mezi daní a důchodem po zdanění.

\section{Obrázek 1: Poměr mezi daní a důchodem po zdanění}

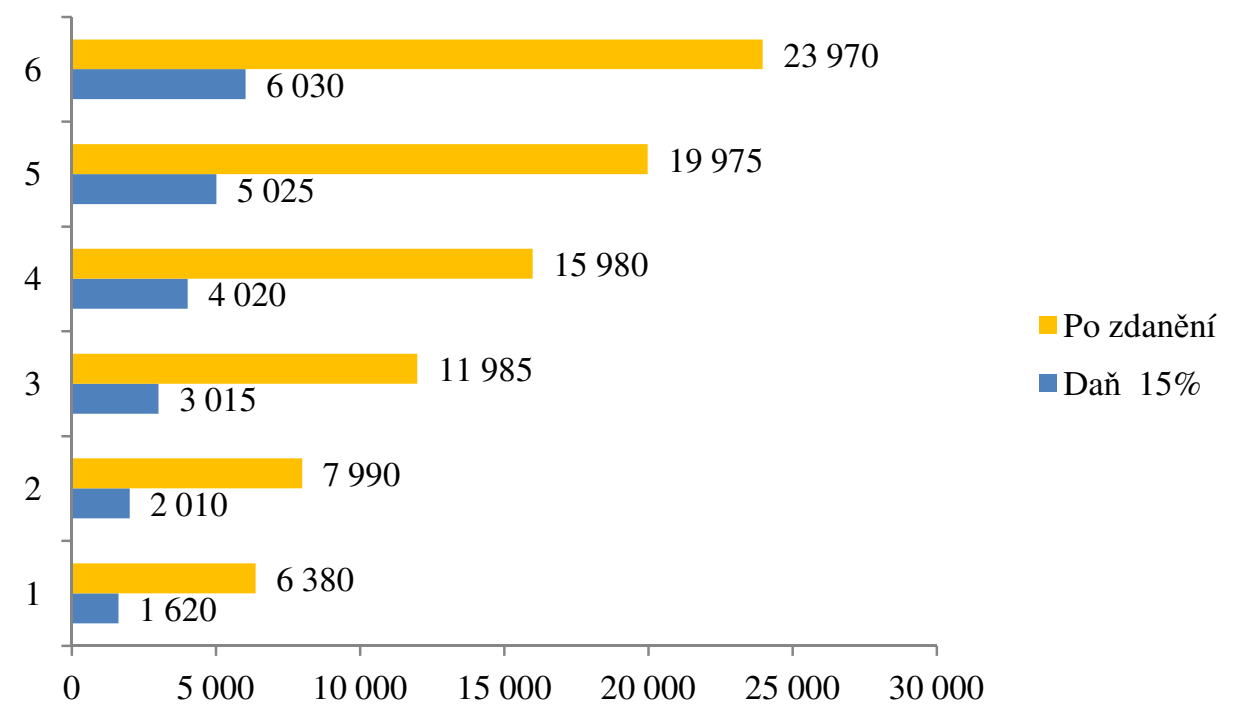

Zdroj: vlastní zpracování autora, údaje z tab. 2

V tabulce 3 je vyčíslena daňová povinnost při základu daně aplikovaném od roku 2013. Nezahrnuje slevy na dani a daňové zvýhodnění, pouze naznačuje lineární nárůst daně s růstem základu daně.

Tabulka 3: Vývoj výše daně při růstu daňového základu v roce 2013

\begin{tabular}{|l|r|r|r|}
\hline \multicolumn{5}{|c|}{ Rok 2013 } \\
\hline Hrubá mzda & Základ daně & \multicolumn{1}{|c|}{ Daň 19 \% } & Po zdanění \\
\hline 8000 & 8000 & $\mathbf{1 5 2 0}$ & 6480 \\
\hline 10000 & 10000 & $\mathbf{1 9 0 0}$ & 8100 \\
\hline 15000 & 15000 & $\mathbf{2 ~ 8 5 0}$ & 12150 \\
\hline 20000 & 20000 & $\mathbf{3 8 0 0}$ & 16200 \\
\hline 25000 & 25000 & $\mathbf{4 7 5 0}$ & 20250 \\
\hline 30000 & 30000 & $\mathbf{5 7 0 0}$ & 24300 \\
\hline
\end{tabular}

Zdroj: vlastní zpracování autora 
Komparací údajů v tabulce 2 a 3 je možné konstatovat, že daňová povinnost poplatníka bude nižší z odvozeného daňového základu, který nebude zahrnovat pojistné odváděné zaměstnavatelem za zaměstnance. Toto tvrzení lze však opřít pouze o zjištěnou daň před uplatněním daňového zvýhodnění na dítě a slev na dani.

\section{Obrázek 2: Průběh lineární sazby daně}

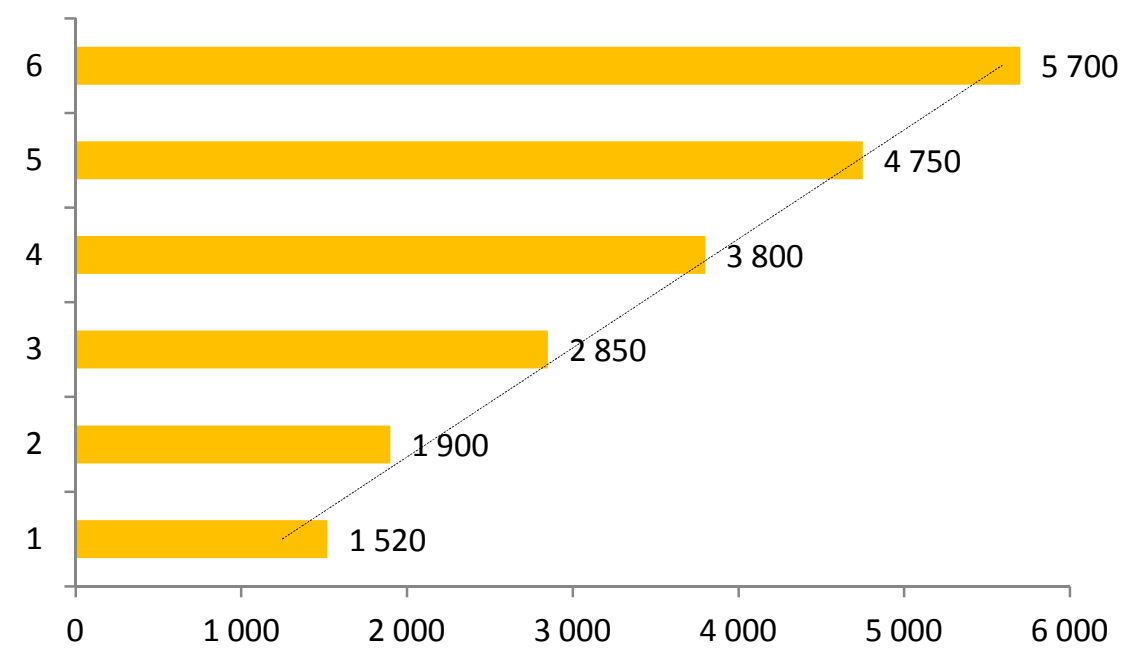

Zdroj: vlastní zpracování autora, údaje z tab. 3

$\mathrm{Z}$ údajů v tabulce 2 a tabulce 3 lze vyčíst daňovou povinnost zaměstnance před uplatnění slev na dani a daňového zvýhodnění. Abychom mohli určit skutečnou daňovou povinnost, doplníme údaje v tabulce o typ slevy na dani.

Vyčísleme tedy čistou mzdu zaměstnance A při dané výši hrubé mzdy, který uplatňuje daňové zvýhodnění na 2 nezaopatřené děti a zaměstnance $\mathbf{B}$, který neuplatňuje žádné daňové zvýhodnění, mimo základní slevu na poplatníka. 
Tabulka 4: Zdanění zaměstnance uplatňujícího si daňové zvýhodnění na 2 děti v roce 2013

\begin{tabular}{|c|c|c|c|c|c|c|c|}
\hline \multicolumn{7}{|c|}{ Zaměstnanec A uplatňuje celkovou slevu na dani ve výši 4304 Kč } \\
\hline $\begin{array}{c}\text { Hrubá } \\
\text { mzda }\end{array}$ & $\begin{array}{c}\text { Základ } \\
\text { daně }\end{array}$ & Daň 19\% & Po zdanění & Daň po slevě & Pojistné & Čistá mzda & $\begin{array}{c}\text { Daň } \\
\text { bonus }\end{array}$ \\
\hline 8000 & 8000 & 1520 & 6480 & 0 & 1040 & 9774 & 2784 \\
\hline 10000 & 10000 & 1900 & 8100 & 0 & 1300 & 11104 & 2404 \\
\hline 15000 & 15000 & 2850 & 12150 & 0 & 1950 & 14504 & 1454 \\
\hline 20000 & 20000 & 3800 & 16200 & 0 & 2600 & 17904 & 504 \\
\hline 25000 & 25000 & 4750 & 20250 & 446 & 3250 & 21304 & 0 \\
\hline 30000 & 30000 & 5700 & 24300 & 1396 & 3900 & 24704 & 0 \\
\hline
\end{tabular}

Zdroj: vlastní zpracování autora, výchozí údaje (základ daně) vyplývá z tab. 2 a tab. 3

Z tabulky 4 můžeme vyčíst také efektivní sazbu daně (podíl daně na základu daně). U hrubé mzdy 8000 Kč, 10000 Kč, 15000 Kč a 20000 Kč je efektivní sazba daně 0 \%. U hrubého př́ijmu 25000 Kč je již 1,78 \% a u příjmu 30000 Kč stoupá na 4,65 \%.

Tabulka 5: Zdanění bezdětného zaměstnance v roce 2013

\begin{tabular}{|c|c|c|c|c|c|c|c|}
\hline \multicolumn{7}{|c|}{ Zaměstnanec B uplatňuje základní slevu na dani ve výši 2070 Kč } \\
\hline $\begin{array}{c}\text { Hrubá } \\
\text { mzda }\end{array}$ & $\begin{array}{c}\text { Základ } \\
\text { daně }\end{array}$ & Daň 19\% & Po zdanění & Daň po slevě & Pojistné & Čistá mzda & $\begin{array}{c}\text { Daň. } \\
\text { bonus }\end{array}$ \\
\hline 8000 & 8000 & 1520 & 6480 & 0 & 1040 & 7510 & 550 \\
\hline 10000 & 10000 & 1900 & 8100 & 0 & 1300 & 8870 & 170 \\
\hline 15000 & 15000 & 2850 & 12150 & 780 & 1950 & 12270 & 0 \\
\hline 20000 & 20000 & 3800 & 16200 & 1730 & 2600 & 15670 & 0 \\
\hline 25000 & 25000 & 4750 & 20250 & 2680 & 3250 & 19070 & 0 \\
\hline 30000 & 30000 & 5700 & 24300 & 3630 & 3900 & 22470 & 0 \\
\hline
\end{tabular}

Zdroj: vlastní zpracování autora, výchozí údaje (základ daně) vyplývá z tab. 2 a tab. 3

Následující obrázek 3 znázorňuje vývoj výše čisté mzdy zaměstnance A, který uplatňuje mimo základní slevu na poplatníka i daňové zvýhodnění na 2 děti, s komparací výše čisté mzdy zaměstnance $\mathrm{B}$, který si uplatňuje pouze základní slevu na poplatníka. Z průběhu křivek A a B je zřejmé, že slevy na dani způsobují, že i jednotná lineární daň se může chovat jako progresivní. Výše čisté mzdy je závislá na užití typu slev na dani.

\footnotetext{
${ }^{7}$ Nárok na daňový bonus vzniká v okamžiku, kdy uplatňované slevy převyšují základní daňovou povinnost. Poplatník má právo požádat stát, aby mu rozdíl (tedy nemožnost uplatnění celé výše slevy) doplatil.

${ }^{8}$ Nárok na daňový bonus vzniká v okamžiku, kdy uplatňované slevy na dani převyšují základní daňovou povinnost. Poplatník má právo požádat stát, aby mu rozdíl (tedy nemožnost uplatnění celé výše slevy) doplatil.
} 
Obrázek 3: Výše čisté mzdy u zaměstnance A a B při aplikaci různého typu slev na dani

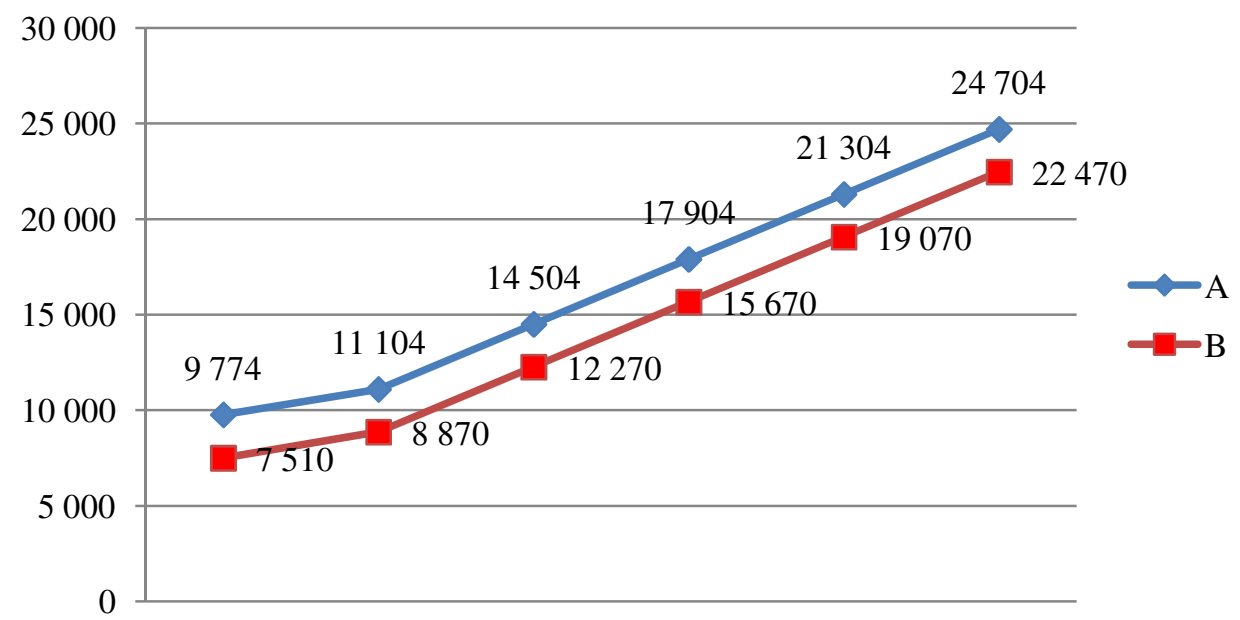

Zdroj: vlastní zpracování autora, údaje z tab. 4 a 5

Na obrázku 4 je naznačen vývoj růstu daňové povinnosti zaměstnance $\mathrm{A}$ i zaměstnance $\mathrm{B}$ ve sledovaném období roku 2013. Vývoj daňové povinnosti by byl ještě více rozdílný, pokud by zaměstnanec A ,čerpal“ ještě jiný typ slevy na dani, např. na postižené dítě. Jeho daňová povinnost by se adekvátně ponížila a čistý prř́jem by se o danou částku zvýšil.

Obrázek 4: Vývoj růstu daňové povinnosti u zaměstnance A a zaměstnance B

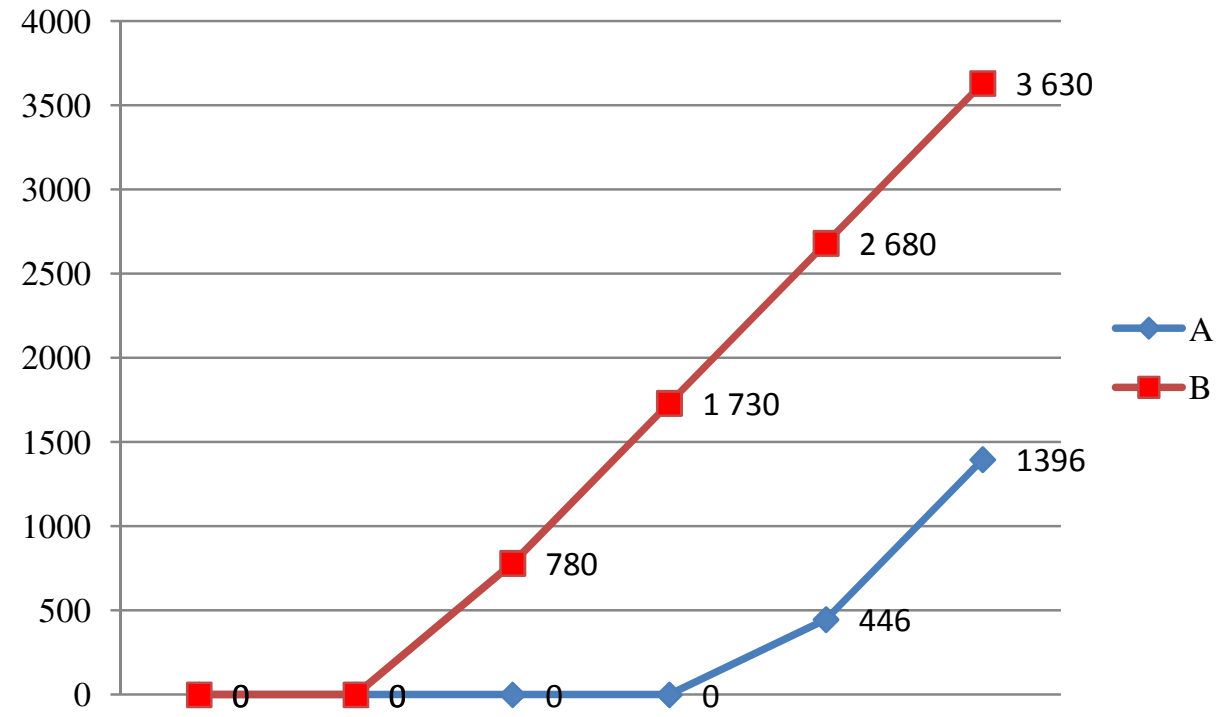

Zdroj: vlastní zpracování autora, údaje z tab. 4 a 5 
Změny schválené od roku 2013 se dotknou také zdanění plátce, tedy zaměstnavatele. Následující tabulky 6 a 7 ukazují odlišnou výši mzdových nákladů zaměstnavatele na zaměstnance $v$ roce 2012 a 2013.

Tabulka 6: Celkové náklady zaměstnavatele na zaměstnance 2012

\begin{tabular}{|c|c|c|}
\hline Hrubá mzda & Základ daně & $\mathbf{2 0 1 2}$ \\
\hline 8000 & 10720 & 10720 \\
\hline 10000 & 13400 & 13400 \\
\hline 15000 & 20100 & 20100 \\
\hline 20000 & 26800 & 26800 \\
\hline 25000 & 33500 & 33500 \\
\hline 30000 & 40200 & 40200 \\
\hline
\end{tabular}

Zdroj: vlastní zpracování autora

$\mathrm{Z}$ tabulky 6 lze vyčíst celkové náklady zaměstnavatele na zaměstnance v roce 2012. Celkové náklady $\mathrm{v}$ tpmto období představují hrubý př́jem zaměstnance navýšený o odvody na pojistném, tedy současnou úroveň superhrubé mzdy.

Rok 2013 přináší pro zaměstnavatele úlevu ve zdanění o celé 2 procentní body (viz. tabulka 7), kdy zaměstnavatelé (plátci) budou platit tzv. daň z úhrnu mezd ve výši $32 \%$. Základem daně z úhrnu mezd bude úhrn př́ijmů ze závislé činnosti a funkčních požitků osob, pokud tyto osoby nebudou účastny pojištění v zahraničí. Komparací výpočtů v tabulce 6 a tabulce 7 je možné konstatovat, že zaměstnavatel vyčíslí úsporu v řádu několika desítek či stovek korun u každého zaměstnance.

Tabulka 7: Zdanění zaměstnavatelů daně z př́ijmů ze závislé činnosti v roce2013

\begin{tabular}{|c|c|c|}
\hline Hrubá mzda & Základ daně & $\mathbf{2 0 1 3}$ \\
\hline 8000 & 8000 & 10560 \\
\hline 10000 & 10000 & 13200 \\
\hline 15000 & 15000 & 19800 \\
\hline 20000 & 20000 & 26400 \\
\hline 25000 & 25000 & 33000 \\
\hline 30000 & 30000 & 39600 \\
\hline
\end{tabular}

Zdroj: vlastní zpracování autora

\section{Inkaso daní v České republice - příjmy ze závislé činnosti}

Skutečné celostátní inkaso daní dosáhlo ke konci roku 2011 výše 726,2 mld. Kč, což představuje 95,6 \% celoročně rozpočtovaného objemu a meziroční nárůst o 15,0 mld. Kč, tj. o 2,1\% (měřeno ke skutečnosti roku 2010). 
Celostátní výnos daně z příjmů fyzických osob dosáhl 133,7 mld. Kč (plnění rozpočtu na 88,5 \%) a byl proti stejnému období roku 2010 vyšší o 2,6 mld. Kč, tj. o 2,0 \%.

$\mathrm{Z}$ celkového inkasa státnímu rozpočtu zůstalo 90,6 mld. Kč, rozpočtům obcí náleželo 31,8 mld. Kč a rozpočtům krajů 11,3 mld. Kč.

Tabulka 8: Vývoj inkasa daně z př́ijmů fyzických osob za období 2002 - 2011 v mld. Kč

\begin{tabular}{|c|c|c|c|c|c|c|c|c|c|c|}
\hline Rok & $\mathbf{2 0 0 2}$ & $\mathbf{2 0 0 3}$ & $\mathbf{2 0 0 4}$ & $\mathbf{2 0 0 5}$ & $\mathbf{2 0 0 6}$ & $\mathbf{2 0 0 7}$ & $\mathbf{2 0 0 8}$ & $\mathbf{2 0 0 9}$ & $\mathbf{2 0 1 0}$ & $\mathbf{2 0 1 1}$ \\
\hline $\begin{array}{c}\text { DPFO (včetně srážkové } \\
\text { daně) }\end{array}$ & 115,2 & 124,0 & 133,3 & 143,7 & 136,9 & 151,5 & 143,3 & 126,7 & 130,0 & 133,7 \\
\hline
\end{tabular}

Zdroj: MFČR, 2011

Rozhodující část této daně tvoří daň z příjmů ze závislé činnosti a z funkčních požitků. Její celostátní inkaso za hodnocený rok 2011 dosáhlo 118,2 mld. Kč, tj. plnění rozpočtu na $97,6 \%$.

Meziročně pak tyto příjmy vzrostly o 5,1 mld. Kč, tj. o 6,7 \% (rozpočet počítal s růstem o 8,3 \% oproti skutečnosti 2010). Podíl této daně na celkových daňových př́ijmech státního rozpočtu činil $10,2 \%$.

Důvody nenaplnění rozpočtovaného očekávání této daně lze spatřovat $\mathrm{v}$ nižším objemu vyplacených mezd a také ve zvýšení celkového objemu vyplácených daňových bonusů na vyživované děti. Ve zdaňovacím období za rok 2010 byla finančními úřady na daňovém bonusu na vyživované dítě vyplacena částka cca 11,1 mld. Kč. Lze předpokládat, že hodnota celkově vyplaceného daňového bonusu na vyživované dítě dosáhla za rozpočtované období roku 2011 výše cca 13,5 mld. Kč.

Vývoj meziročního inkasa v roce 2011 byl ovlivněn také snížením slevy na poplatníka z částky 24840 Kč na částku 23640 Kč. Změna výše slevy na poplatníka o částku 100 Kč měsíčně, tzv. ,povodňovou daň“ byla upravena zákonem č. 346/2010 Sb. Tato úprava platila pouze na období roku 2011. Současně se změnou výše slevy na dani pro poplatníka byla ve výdajích rozpočtové kapitoly Všeobecná pokladní správa zřízena nová položka „Prostředky k odstranění důsledků povodní a na následnou obnovu“ v celkové výši 4 mld. Kč, která se rovná odhadu částky, o kterou byly příjmy státního rozpočtu díky tzv. ,,povodňové stokoruně“ zvýšeny. Přesnou celkovou vybranou výši ve věci tzv. ,povodňové daně“ nelze zjistit, nebot' je tato částka součástí celého výnosu daně z př́ijmů fyzických osob a je možno ji pouze kvalifikovaně odhadnout ${ }^{9}$.

Pokud budeme sledovat vývoj inkasa daně z př́ijmu ze závislé činnosti v delším časovém horizontu (viz. tabulka 9) a provedeme meziroční komparaci u této daně, pak můžeme konstatovat, že v období zavedení institutu superhrubé mzdy došlo k propadu ve výběru z této daně.

Inkaso daně z př́ijmu fyzických osob ze závislé činnosti dosáhlo v roce 2007 výše 125,94 mld. Kč. O rok později, tj. v roce 2008 , to bylo o celých 10 mld. méně, tedy 115,18 mld.. Vývoj inkasa zde naznačuje, že superhrubá mzda doprovázela pokles inkasa, který

\footnotetext{
${ }^{9}$ Př́ijmy státního rozpočtu za rok 2011. MFČR [online]. Poslední úprava březen 2012 [cit. 201-25-6]. Dostupné z: http://www.mfcr.cz/cps/rde/xbcr/mfcr/SZU2011_C-II.pdf.
} 
pokračoval ještě v roce 2009 , kdy v meziročním srovnání činila výše výběru z této daně 111,04 mld. Kč, tj. další propad ve srovnání s rokem 2008 o 4,14 mld. a ve srovnání s rokem 2007 celých 14,8 mld. Kč. Rok 2010 vykazuje v meziročním srovnání př́ijem z daně ze závislé činnosti 111,84 mld. Kč. ${ }^{10}$

I přes zřetelné snížení inkasa z příjmu ze závislé činnosti ve sledovaném období 2007 - 2010 není možné říci, že superhrubá mzda způsobila pokles inkasa daně z př́ijmů fyzických osob ze závislé činnosti. Hlavní přičinou uvedeného vývoje byly jednoznačně dopady hospodářské krize. V letech 2008 a 2009 byl totiž zaznamenán dramatický meziroční pokles evidenčního počtu zaměstnanců.

Tabulka 9: Vývoj inkasa daně z příjmů ze závislé činnosti v období 2006 - 2011

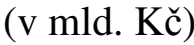

\begin{tabular}{|l|c|c|c|c|c|c|}
\hline Rok & $\mathbf{2 0 0 6}$ & $\mathbf{2 0 0 7}$ & $\mathbf{2 0 0 8}$ & $\mathbf{2 0 0 9}$ & $\mathbf{2 0 1 0}$ & $\mathbf{2 0 1 1}$ \\
\hline $\begin{array}{l}\text { DPFO ze závislé } \\
\text { činnosti }\end{array}$ & 111,6 & 125,9 & 115,2 & 111,0 & 111,8 & 118,2 \\
\hline
\end{tabular}

Zdroj: MFČR, 2011

\section{Závěr}

Zdanění práce je aplikováno v různých ekonomikách odlišně. Je velmi diskutovaným tématem politické, odborné i laické veřejnosti. Metodika zdanění práce prochází změnami v závislosti na aktuální ekonomické, př́ípadně politické situaci dané země. Stává se předmětem prognózování ekonomického vývoje země. Česká republika po mnoha letech uplatňování progresivních sazeb daně u zdanění př́ijmů ze závislé činnosti, přistoupila v roce 2008 k zavedení konceptu tzv. superhrubé mzdy, který přinesl řadu klíčových změn pro poplatníka DPFO, ale také zaměstnavatele i př́ímovou stránku státního rozpočtu. Daňová povinnost poplatníka je $\mathrm{v}$ současné době zjišt'ována $\mathrm{z}$ jeho hrubého prŕíjmu navýšeného o odvody na pojistném zaměstnavatele. Jeho základ daně je tak navýšen o $34 \%$, což představuje logické zvýšení daňové povinnosti. Toto navýšení je kompenzováno tzv. balíku slev na dani. Tyto slevy spolu s daňovým zvýhodněním zachovávají ve své podstatě progresivní charakter zdanění mzdy zaměstnance, a to i přes to, že je od roku 2008 aplikována jediná lineární sazba daně DPFO ve výši $15 \%$.

Schválený návrh reformních změn datovaných k 1. lednu 2013 přináší zrušení institutu superhrubé mzdy při zachování lineární sazby daně, byt's odlišně stanovenou výší sazby. Dle simulace výpočtů vyplývá, že v okamžiku zrušení superhrubé mzdy dojde k významnému snížení daňového základu poplatníka, z kterého se bude zjišt'ovat jeho daňová povinnost. Výše sazby daně z př́ijmů fyzických osob bude $19 \%$. Současně však bude navýšena procentuální výše odvodu na zdravotní pojištění hrazeného poplatníkem (zaměstnancem) o 2 procentní body, tedy na stejnou výši jako je sazba pro sociální pojištění v roce 2011. Návrh počítal se zavedením výdajového paušálu pro zaměstnance ve výši 3000 Kč ročně, dnes se však již s tímto paušálem minimálně pro 2013 nepočítá. Základní sleva na poplatníka zůstane na úrovni roku 2012, tj. 2070 Kč, přičemž si tuto slevu budou moci nárokovat pouze zaměstnanci, jejichž příjem nepřevýší 4násobek průměrné mzdy. Celkové mzdové náklady

\footnotetext{
${ }^{10}$ Upřesněné výsledky pokladního plnění státního rozpočtu ČR za rok 2010. $M F \breve{C} R$ [online]. Poslední úprava 10. ledna 2011 [cit. 2011-27-4]. Dostupné z:

http://www.mfcr.cz/cps/rde/xchg/mfcr/xsl/tiskove_zpravy_ministerstva_59843.html?year=2011
} 
zaměstnavatele klesnou o $2 \%$, protože odvody na pojistném za zaměstnance ve výši $34 \%$ z hrubé mzdy budou nahrazeny jednotnou 32\%ní sazbou daně z úhrnu mezd.

Realizace schváleného reformního návrhu o zrušení konceptu superhrubé mzdy v součinnosti $\mathrm{s}$ aplikací dalších reformních opatření souvisejících se zdaněním příjmů ze závislé činnosti by měla $\mathrm{v}$ konečném důsledku přinést úsporu jak zaměstnanci, tak zaměstnavateli $\mathrm{v}$ řádu několika desítek či stovek korun měsíčně.

\section{Literatura:}

[1] KUBÁTOVÁ, K.: Daně a daňová politika. Praha: ASPI, 2006. ISBN 80-7357-205-2.

[2] LÁCHOVÁ, L.: Daňové systémy v globálním světě. Praha: ASPI, 2007. ISBN 978-807357-320-1.

[3] ŠIROKÝ, J.: Daňová teorie s praktickou aplikací. Praha: C. H. Beck, 2008. ISBN 97880-7400-005-8.

[4] Mzdy a náklady práce. ČSÚ [online]. Poslední úprava 9. března 2011. [cit. 2011-07-4]. Dostupné z: http://www.czso.cz/csu/redakce.nsf/i/prace_a_mzdy_prace

[5] OECD: Kde jsou nejvyšší čisté mzdy? Finance [online]. Poslední úprava 7. prosince 2010 [cit. 2011-07-4]. Dostupné z: http://www.finance.cz/zpravy/finance/290168/

[6] Upřesněné výsledky pokladního plnění státního rozpočtu ČR za rok 2010. MFČR [online]. Poslední úprava 10. ledna 2011 [cit. 2011-27-4]. Dostupné z: http://www.mfcr.cz/cps/rde/xchg/mfcr/xsl/tiskove_zpravy_ministerstva_59843.html?ye $\operatorname{ar}=2011$

[7] Pokladní plnění státního rozpočtu ČR za leden až březen 2011. MFČR [on line]. Poslední úprava 29. března 2011 [cit. 2011-17-4]. Dostupné z: http:// www.mfcr.cz/cps/rde/xchg/mfcr/xsl/tiskove_zpravy_ministerstva_61459.html?year=PR ESENT

[8] Zákon č. 586/1992 Sb., zákon o dani z př́ijmu

[9] Zákon č. 262/2006 Sb., zákoník práce § 109 - §144

\section{JEL H20, H21, H24}

\section{Ing. Marcela Prausová}

Obchodně podnikatelská fakulta v Karviné

Slezská univerzita v Opavě

Univerzitní náměstí 1934/3, 73340 Karviná

marcela.prausova@seznam.cz 